\title{
Knowledge Regarding Management of Patients with Central Venous Access Devices among ICU Nurses
}

\author{
Latha U S ${ }^{1}$, Kusum Gurung ${ }^{2}$ \\ ${ }^{1}$ Lecturer, Child Health Nursing, M S Ramaiah Institute of Nursing Education and Research, Bangalore-560054. \\ ${ }^{2}$ Lecturer, Mental Health Nursing, M S Ramaiah Institute of Nursing Education and Research, \\ Bangalore-560054. \\ Corresponding Author: Latha U S
}

DOI: https://doi.org/10.52403/ijhsr.20220212

\begin{abstract}
Central venous access devices are now commonly used in critical care units as most of these patients need a very long access. Improper management of patient with central venous catheter can give rise to various life-threatening complications. As technology is advancing at a rapid speed, nurses involved in patient care should be up to date their knowledge while providing care to patients to improve the health of patients and to prevent development of complication.

Objectives: To assess the knowledge regarding management of patient with central venous access devices among Intensive care unit (ICU) nurses and to find out the association between knowledge regarding management of patient with central venous access device and their socio demographic variables.

Materials and Methods: A descriptive research design was adopted for the study. Samples were selected by using non-probability convenient sampling techniques and consists of 60 nurses working in Intensive care unit of selected hospital, Bangalore. Data was collected using structured knowledge questionnaire.

Results: The result of the study revealed that majority 25 (41.67\%) of the ICU nurses had inadequate knowledge, $34(56.67 \%)$ had moderately adequate knowledge, and only $1(1.67 \%)$ nurses had adequate knowledge regarding management of patient with central venous access devices. The study findings showed that there is no significant relationship between knowledge regarding CVAD management and the selected social-demographic variables.

Interpretation and Conclusion: The study concluded that majority of the nurses working in Intensive care units had inadequate knowledge regarding management of patient with central venous access device. The nurse should be periodically evaluated to assess their knowledge and practice and organise in-service education according to the needs of the nurses.
\end{abstract}

Key Words: Knowledge, Central venous access device, Intensive care unit, Nurses

\section{INTRODUCTION}

People with life threatening injuries and illness need critical care. It usually takes place in an ICU or trauma center, where monitors, intravenous tubes, feeding tubes, catheters, ventilators and other equipment are common. These can sustain life but can also increase the risk of infection. ${ }^{1}$ For the management of critically and chronically ill patients, intravascular catheters have become essential devices. However, their usage is associated with serious infections; complications resulting in significant morbidity, increased duration of hospitalization and additional medical costs. $^{2}$

Healthcare Associated Infections (HAI), previously known as Nosocomial Infections are the fourth leading cause of death among hospitalized patients. Centers 
of Disease Control and Prevention data reports a nosocomial infection rate of $5 \%$, out of which $10 \%$ are blood stream related infections and $15 \%$ attributed mortality rate. 3 A study conducted at Escort Heart Centre, New Delhi, showed that mortality due to central venous catheter related blood stream infections was $22.9 \%$ compared to $0.2 \%$ in non-central venous catheter related blood stream infections. ${ }^{4}$

Most CVAD related infections are preventable and different measures have been implemented to reduce the risk for catheter related infections including maximal barrier precautions during catheter insertion, catheter site maintenance and hub handling. ${ }^{5}$ An international descriptive survey of 34 countries done during January to February 2016 related to central venous access device infection and complication, it revealed a varying consistency in routine central venous access device site care practice and a wide variance in the management of central venous access device site due to the lack of related written policies and procedures. ${ }^{6}$

\section{OBJECTIVES OF THE STUDY:}

1. To assess the knowledge regarding management of patient with central venous access device among ICU nurses.

2. To find out the association between knowledge regarding management of patient with central venous access device and their socio demographic variables.

\section{MATERIALS AND METHODS}

A descriptive research design was adopted for the study. After obtaining formal permission from the concerned authority to conduct the study, 60 nurses working in intensive care units of selected Hospitals, Bangalore were selected using non-probability convenient sampling technique. Informed consent was obtained assuring maximum anonymity from the participants who fulfilled the inclusion criteria. The inclusion criteria to participate in the study were nurses who were working in Intensive care units and present during the time of study. Data collection was performed using baseline data sheet for sociodemographic variable and a structured knowledge questionnaire to assess knowledge regarding management of central venous access device which was prepared by the investigators after a thorough review of literature, and validated by six experts. The structured knowledge questionnaire included questions on knowledge regarding insertion of central venous access device, assessment and dressing of site with central venous access device.

Each correct answer carried one mark and wrong answer carried zero mark. Thus a total of 30 marks were given for knowledge assessment. Level of knowledge was interpreted based on scores. Nurses who scored less than 15 marks were categorized below $50 \%$ and considered as inadequate level of knowledge, nurses who scored between 16-23 marks were categorized under $50-75 \%$ and considered as moderately adequate level of knowledge, and nurses who scored $\geq 24$ marks were categorized above $75 \%$ and considered as adequate level of knowledge.

\section{STATISTICAL ANALYSIS}

Data was analyzed using statistical package software for social sciences (SPSS) version 21. Frequency and percentage distribution were used to describe sociodemographic data and level of knowledge. Chi square test was done to determine association between demographic characteristics and the variables. Confidence interval was set at $95 \%$ and $\mathrm{P}<0.05$ was considered statistically significant.

\section{RESULT}

Table 1 showed that majority of ICU nurses $38(63.33 \%)$ were in the age group of 21- 30 years, and $45(75 \%)$ of them were females. Education status of ICU nurses varied with majority of ICU nurses 44 (73.33\%) having diploma in general nursing followed by $15(25 \%)$ having B.Sc. 
Latha U S et.al. Knowledge regarding management of patients with Central venous access devices among ICU nurses.

Nursing. In relation to the area of work; majority of nurses $48(88 \%)$ were from the medical and neuro intensive care unit, and most of the nurses $17(28.33 \%)$ had $1-3$ years of experience. With respect to monthly income, majority of nurses 28
(48.34) had income above Rs 20,000/, and majority of nurses $37(61.67 \%)$ had not undergone any in-service education programme on Central venous access device (CVAD).

Table 1: Socio demographic characteristics of ICU Nurses $(n=60)$

\begin{tabular}{|c|c|c|c|c|}
\hline SL NO & BASELINE VARIABLES & CATEGORY & FREQUENCY & PERCENTAGE \\
\hline \multirow[t]{3}{*}{1} & \multirow[t]{3}{*}{ Age (in years) } & $21-30$ & 38 & 63.33 \\
\hline & & $32-40$ & 21 & 35.00 \\
\hline & & $41-50$ & 1 & 1.67 \\
\hline \multirow[t]{2}{*}{2} & \multirow[t]{2}{*}{ Gender } & Male & 15 & 25 \\
\hline & & Female & 45 & 75 \\
\hline \multirow[t]{3}{*}{3} & \multirow[t]{3}{*}{ Education } & GNM & 44 & 73.33 \\
\hline & & B.Sc. Nursing & 15 & 25.00 \\
\hline & & M.Sc. Nursing & 1 & 1.67 \\
\hline \multirow[t]{4}{*}{4} & \multirow[t]{4}{*}{ Area of work } & PICU/NICU & 6 & 10.00 \\
\hline & & Emergency ICU & 0 & 0 \\
\hline & & MICU/Neuro ICU & 48 & 80.00 \\
\hline & & Step down ICU & 6 & 10.00 \\
\hline \multirow[t]{4}{*}{5} & \multirow[t]{4}{*}{ Year of experience } & $1-3$ years & 17 & 28.33 \\
\hline & & 4-6 years & 15 & 25.00 \\
\hline & & $7-9$ years & 12 & 20.00 \\
\hline & & Above 9 years & 16 & 26.67 \\
\hline \multirow[t]{4}{*}{6} & \multirow[t]{4}{*}{ Monthly income } & $5,000-10,000$ & 11 & 18.33 \\
\hline & & $10,000-15,000$ & 11 & 18.33 \\
\hline & & $15,000-20,000$ & 9 & 15.00 \\
\hline & & $\begin{array}{l}\text { Above } 20,000 \\
\end{array}$ & 29 & 48.34 \\
\hline \multirow[t]{2}{*}{7} & \multirow[t]{2}{*}{ In-service education on CVAD in 1 year } & YES & 23 & 38.33 \\
\hline & & NO & 37 & 61.67 \\
\hline
\end{tabular}

Table 2: Frequency and Percentage distribution of level of knowledge of nurses regarding management of patients with central venous access device.

\begin{tabular}{|c|l|c|c|}
\hline $\begin{array}{r}\text { Sl } \\
\text { No }\end{array}$ & Aspects Of Knowledge & Frequency & Percentage \\
\hline 1 & $\begin{array}{l}\text { Inadequate Knowledge } \\
(<=50 \%)\end{array}$ & 25 & $41.67 \%$ \\
\hline 2 & $\begin{array}{l}\text { Moderately Adequate } \\
\text { Knowledge } \\
(51-75 \%)\end{array}$ & 34 & $56.67 \%$ \\
\hline 3 & $\begin{array}{l}\text { Adequate Knowledge } \\
(>75 \%)\end{array}$ & 1 & $1.67 \%$ \\
\hline
\end{tabular}

Table 2 reveals that $25(41.67 \%)$ nurses had inadequate knowledge, 34 $(56.67 \%)$ nurses had moderately adequate knowledge and only $1(1.67 \%)$ nurses had adequate knowledge regarding management of patient with Central venous access device. The above data is depicted in figure 1.

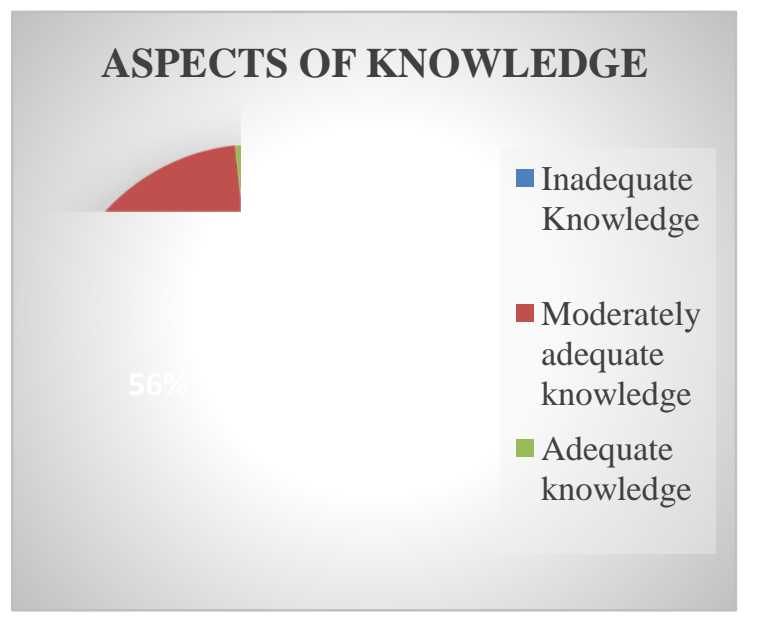

Figure 1: Percentage distribution of level of knowledge of ICU nurses regarding management of patient with CVAD

Table 3: Association of knowledge level of nurses with selected socio demographic variables. $n=60$

\begin{tabular}{|c|c|c|c|c|c|c|}
\hline \multirow[t]{2}{*}{$\begin{array}{l}\text { SL. } \\
\text { No. }\end{array}$} & $\begin{array}{ll}\text { Socio-Demograph } & \text { HIC } \\
\text { Variables } & \end{array}$ & \multicolumn{3}{|c|}{ Level of knowledge } & \multirow{2}{*}{$\begin{array}{l}\text { CHI } \\
\text { SQUARE } \\
\qquad x^{2}\end{array}$} & \multirow[t]{2}{*}{$\begin{array}{l}\text { P- } \\
\text { VALUE }\end{array}$} \\
\hline & & $\begin{array}{l}\text { Inadequate } \\
\text { knowledge }\end{array}$ & $\begin{array}{c}\text { Moderately adequate } \\
\text { knowledge }\end{array}$ & $\begin{array}{l}\text { Adequate } \\
\text { knowledge }\end{array}$ & & \\
\hline \multirow[t]{4}{*}{1} & & & AGE IN YEARS & & \multirow{4}{*}{$\begin{array}{c}0.683 \\
\mathrm{df}=4\end{array}$} & \multirow{4}{*}{$\begin{array}{l}0.953 \\
\text { (NS) }\end{array}$} \\
\hline & $21-30$ & 16 & 22 & 1 & & \\
\hline & $31-40$ & 9 & 11 & 0 & & \\
\hline & $41-50$ & 0 & 1 & 0 & & \\
\hline \multirow[t]{3}{*}{2} & & & GENDER & & \multirow{3}{*}{$\begin{array}{l}2.15 \\
\mathrm{df}=2\end{array}$} & \multirow{3}{*}{$\begin{array}{l}0.341 \\
\text { (NS) }\end{array}$} \\
\hline & Male & 4 & 11 & 0 & & \\
\hline & Female & 21 & 23 & 1 & & \\
\hline
\end{tabular}


Latha U S et.al. Knowledge regarding management of patients with Central venous access devices among ICU nurses.

\begin{tabular}{|c|c|c|c|c|c|c|}
\hline \multicolumn{7}{|c|}{ Table 3 Continued... } \\
\hline \multirow[t]{4}{*}{3} & & EDI & QUA & & \multirow{4}{*}{$\begin{array}{l}3.37 \\
\mathrm{df}=4\end{array}$} & \multirow{4}{*}{$\begin{array}{c}0.498 \\
\text { (NS) }\end{array}$} \\
\hline & GNM & 17 & 26 & 0 & & \\
\hline & Bsc Nursing & 8 & 7 & 1 & & \\
\hline & Msc Nursing & 0 & 1 & 0 & & \\
\hline \multirow[t]{4}{*}{4} & \multicolumn{4}{|c|}{ AREA OF WORK } & \multirow{4}{*}{$\begin{array}{l}8.68 \\
\mathrm{df}=4\end{array}$} & \multirow{4}{*}{$\begin{array}{c}0.070 \\
\text { (NS) }\end{array}$} \\
\hline & AICU/NICU & 4 & 2 & 0 & & \\
\hline & MICU/Neuro ICU & 15 & 31 & 1 & & \\
\hline & Stepdown ICU & 6 & 1 & 0 & & \\
\hline \multirow[t]{5}{*}{5} & & & $\mathbf{L} \mathbf{E}$ & & \multirow{5}{*}{$\begin{array}{l}3.79 \\
\mathrm{df}=6\end{array}$} & \multirow{5}{*}{$\begin{array}{l}0.705 \\
\text { (NS) }\end{array}$} \\
\hline & $1-3$ Years & 6 & 11 & 0 & & \\
\hline & 4-6 Years & 5 & 10 & 0 & & \\
\hline & 7-9 Years & 6 & 5 & 0 & & \\
\hline & Above 9 years & 8 & 8 & 1 & & \\
\hline \multirow[t]{5}{*}{6} & & & HLY & & \multirow{5}{*}{$\begin{array}{l}4.34 \\
\mathrm{df}=6\end{array}$} & \multirow{5}{*}{$\begin{array}{c}0.630 \\
\text { (NS) }\end{array}$} \\
\hline & $5000-10000$ & 4 & 7 & 0 & & \\
\hline & $10000-15000$ & 7 & 4 & 0 & & \\
\hline & $15000-20000$ & 2 & 7 & 0 & & \\
\hline & Above 20000 & 12 & 16 & 1 & & \\
\hline \multirow[t]{3}{*}{7} & & & E EI & & \multirow{3}{*}{$\begin{array}{l}1.74 \\
\mathrm{df}=2\end{array}$} & \multirow{3}{*}{$\begin{array}{c}0.419 \\
\text { (NS) }\end{array}$} \\
\hline & Yes & 12 & 11 & 0 & & \\
\hline & No & 13 & 23 & 1 & & \\
\hline
\end{tabular}

Table 3 shows association of knowledge with selected socio demographic variables. The calculated chi-square value was less than the table value for all socio demographic variables at level of significance $\mathrm{P}<0.05$. Hence research hypothesis 1 there is significant association between the level of knowledge of nurses and selected socio-demographic variables was rejected.

\section{DISCUSSION}

The present study revealed that 25 (41.67\%) nurses had inadequate knowledge, $34(56.67 \%)$ nurses had moderately adequate knowledge, and only $1(1.67 \%)$ nurses had adequate knowledge regarding management of patient with central venous access device. The mean percentage obtained for overall knowledge was $16.016 \%$ with the standard deviation of $3.725 \%$ which showed that nurses had moderately adequate knowledge.

The study findings are supported by a study conducted on "Assessment of nurses knowledge on care of patient with central venous catheter" at GLASGOW hospital, United Kingdom, the study shows that $68 \%$ of the nurses were having inadequate knowledge and $32 \%$ had moderately adequate knowledge, none of the nurses was found to have adequate knowledge. ${ }^{3}$
The analysis was done for association between the levels of knowledge of nurses with selected socio-demographic variables using chi-square test. The computed chi-square value was lesser than the table value at $\mathrm{P}<0.05$, level of significance. Hence the research hypothesis $\mathrm{H} 1$, there is a significant association between level of knowledge of nurses and selected socio-demographic variables was rejected.

The study findings are supported by a study done to assess Intensive care unit nurses among selected hospitals of United States. The study proved that nurse's knowledge about care of central venous catheter is not adequate and the selected socio- demographic variables of the staff nurses showed no association with better score on the test and knowledge. ${ }^{4}$

\section{CONCLUSION}

The overall knowledge of nurses on management of patient with CVAD, 25 $(41.67 \%)$ nurses had inadequate knowledge, $34(56.67 \%)$ nurses had moderately adequate knowledge and $1(1.67 \%)$ nurse had adequate knowledge. Hence the nurse working in intensive care units should be periodically evaluated to assess their knowledge and practice. In-service education can be planned according to the needs of the nurses. 


\section{Acknowledgement: None}

\section{Conflict of Interest: None}

\section{Source of Funding: None}

\section{Ethical Approval: Approved}

\section{REFERENCES}

1. Wilma PJ, Long BC. Shafer's Medical nursing. New Delhi: B. T. Publication; 1995. p 404- 05.

2. Stewart BP, Strawn RM. Ready reference for critical care. Sudbury: Jones and Barlet Publication; 2004. p280 - 86.

3. Jose M, Nurses knowledge and practice regarding hand washing practices surrounding CVAD care in Varalaxmi medical college [Internet]. 2016 Nov [cited 2017 Apr 14]. Available from: URL=http://www.rguhs.ac.in/cdc/onlinecdc

4. Reti RK, Vass E. Intensive Care Unit nurses knowledge of evidence based guidelines for preventing central venous catheter related infection [Internet]. Orv Hetil: 2008 [cited 2017 Jan 21]; 149(20): 929-32. Available from: http://www.ajccon line.org.

5. Suzanne SC, Brenda BG. Brunner and Suddharths Medical Surgical Nursing. Philadelphia: Lippincott publishers; 2004. p677 - 697.

6. Babu GK, Babu MC. Outcomes, cost comparison and patient satisfaction during long- term central venous access in cancer patients [Internet]. Journal Medical Paediatric Oncology; 2016 Oct [cited 2017 May 15]; 232-38. Available from: https://www.ncbi.nlm.nih.gov/pmc/articles/ PMC5234158.

How to cite this article: Latha U S, Kusum Gurung. Knowledge regarding management of patients with central venous access devices among ICU nurses. Int J Health Sci Res. 2022; 12(2): 91-95. DOI: https://doi.org/10.52403/ ijhsr.20220212 